\title{
Performance dos apresentadores dos telejornais: a construção do éthos*
}

\section{RESUMO}

Do "locutor de notícias", que se limitava a ler as informações com atitude distanciada e em estilo radiofônico, ao "âncora", que se posiciona enfaticamente sobre os fatos noticiados, podemos observar, grandes transformações nos perfis dos apresentadores de telejornal. É possível identificar, especialmente a partir dos anos 90, uma tendência geral à personalização dos apresentadores, provocando, conseqüentemente, uma mudança na própria retórica dos telejornais. Essa nova estratégia retórica dos telejornais depende, agora, da ênfase dada à construção do éthos dos seus apresentadores (uma imagem construída pelo próprio discurso). Este estudo aponta características definidoras de quatro tipos de éthos entre os apresentadores brasileiros, indicando como sua configuração é determinada, preliminarmente, pelas estratégias enunciativas adotadas pelos telejornais.

\section{PALAVRAS-CHAVE}

telejornal

apresentador

éthos

\section{ABSTRACT}

From "newscaster", who was limited to reading information with a distanced demeanor and radiophonic style, to "anchor", who emphatically takes positions on the facts reported, we see considerable transformations in the profile of television news presenters. Especially beginning in the 1990s, it is possible to identify a general tendency toward the personalization of the presenters, consequently leading to a change in the very rhetoric of television news. This new rhetoric strategy now depends upon the emphasis given to the construction of the ethos of its presenters (an image constructed by the discourse itself). The present study addresses defining characteristics of four types of ethos among Brazilian news presenters, indicating how their configuration is preliminarily determined by the discourse strategies adopted by television news programs.

\section{KEY WORDS}

television news

apresenter

ethos

\section{Yvana Fechine}

Professora do Departamento de Comunicação Social do Programa de PósGraduação da UFPE/PE/BR yvanafechine@uol.com.br

\section{Um novo perfil de apresentador}

A credibilidade do telejornal é influenciada diretamente pela confiança que os espectadores depositam nos seus apresentadores. Embora possam ser considerados, como em qualquer outro formato televisual, a "cara" do programa que comandam, os apresentadores do telejornal, diferentemente dos profissionais que desempenham este papel em outros gêneros, constroem sua imagem numa constante tensão entre a propalada exigência de "objetividade" e imparcialidade da prática jornalística e a autopromoção e glamourização inerentes à televisão. Se, antes, os apresentadores primavam pela discrição em relação à sua vida pessoal, hoje, muitos deles se comportam como celebridades, sendo objeto freqüente de revistas, sites e programas de TV dedicados aos "famosos" ou a fofocas do meio artístico. Jornalistas de grandes emissoras, como Fátima Bernardes e Wiliam Bonner, apresentadores do famoso Jornal Nacional (JN), chegam a ser retratados na mídia como "míticas estrelas hollywoodianas dos anos dourados do star system" (Hagen e Machado, 2006, p. 2). Do "locutor de notícias", que se limitava a ler as informações com atitude distanciada e em estilo radiofônico, ao "âncora", que se posiciona enfaticamente sobre os fatos noticiados, podemos observar, grandes transformações não somente nos papéis, mas nas posturas e perfis dos apresentadores de telejornal.

Hoje, é cada vez mais fácil apontar apresentadores de telejornal que esbravejam contra os políticos ou criticam duramente as instituições cobrando "soluções" em nome do "povo", evidenciando com clareza posturas ideológicas. Há ainda outros que, assumindo um estilo mais descontraído, fazem brincadeiras com a equipe ou com o próprio espectador, revelam situações do seu cotidiano (a reação que tiveram com a vacina conta gripe, por exemplo), comportamentos privados (o que faz quando está de folga, por exemplo) e gostos individuais (o time pelo qual torce, por exemplo) em meio aos comentários feitos às reportagens apresentadas pelo telejornal.

Por meio de tais comportamentos, o apresentador passa, por um lado, a ser percebido paulatinamente pelo público como alguém mais próximo e familiar, alguém de quem ele conhece até alguns aspectos da vida, das experiências, das opiniões e preferências pessoais. Pode ainda, por outro lado, ser visto pelo telespectador como alguém capaz de defender seus interesses e manifestar suas posições, apto a expressar às autoridades, aos políticos ou a representantes da sociedade civil aquilo que ele próprio gostaria de falar. Por um ou por outro caminho, com diferentes gradações e estratégias de manifestação, é possível indicar, especialmente a partir dos anos 
90, uma tendência geral à personalização desses apresentadores, provocando, assim, também uma mudança na própria retórica dos telejornais. Essa nova estratégia retórica sustenta-se na ênfase dada, agora, na construção do éthos dos apresentadores por meio de procedimentos determinados preliminarmente pelas estratégias enunciativas dos telejornais. Para entender como isso se dá, é preciso não apenas recuperar alguns pressupostos da retórica aristotélica, mas também discorrer, antes, sobre a própria enunciação no telejornal.

\section{Telejornal e enunciação'}

Do ponto de vista enunciativo, o telejornal pode ser tratado como um enunciado englobante (o noticiário como um todo) que resulta da articulação, por meio de um ou mais apresentadores, de um conjunto de outros enunciados englobados (as notícias) que, embora autônomos, mantêm uma interdependência. Podemos, assim, conceber o telejornal como um conjunto que emerge justamente da articulação dessas sucessivas unidades numa instância enunciativa que as engloba. Nas suas mais variadas formas - reportagens gravadas, entrevistas no estúdio, entradas "ao vivo", gráficos, material de arquivo etc. -, todos os enunciados englobados (partes) organizam-se como um enunciado englobante implícito (todo) ao serem inseridos e articulados entre si numa mesma temporalidade definida pelo início e pelo fim do programa. A temporalidade na qual se dá a própria transmissão do telejornal corresponde a uma duração continuamente no presente. É nesta duração que o telejornal se faz no momento mesmo em que se exibe.

Este enunciado englobante (o telejornal) não se define como tal apenas pela sucessividade das suas unidades constitutivas (reportagens, links ao vivo etc.) numa temporalidade que articula o sintagma audiovisual. Definese também a partir de uma pessoa (um "eu") e de um espaço de referência. Todo ato de enunciação é, afinal, a instância de instauração de um eu, de um aqui e de um agora, a partir dos quais se definem, por projeção, as mesmas categorias no enunciado. É importante, no entanto, distinguir duas instâncias no procedimento enun-

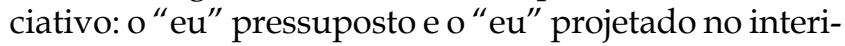
or do enunciado e, respectivamente, um " $\mathrm{tu}$ " pressuposto e um "tu" projetado no interior do enunciado, já que a cada "eu" corresponde um "tu" (quem fala sempre fala para alguém). Estes "eu" e "tu" pressupostos, destinador e destinatário implícitos da enunciação, são denominados, respectivamente de enunciador e enunciatário. Tanto quanto a enunciação, os actantes deste nível são também instâncias conceituais, "sujeitos lógicos" ou papéis passíveis de figurativização apenas no nível mais concreto do enunciado. Neste caso, instauram-se no enunciado sujeitos delegados do enunciador e do enunciatário denominados, respectivamente, de narrador e narratário. Estes nada mais são do que o "eu" e "tu" projetados: simulacros ou figurativizações, construídos no e pelo próprio enunciado, do enunciador e do enunciatário, respectivamente.

No esquema de papéis definidos tradicionalmente na teoria da enunciação, o enunciador e o enunciatário não podem ser confundidos com o autor e leitor empíricos. Estes últimos só podem ser levados em conta, no campo da enunciação, também a partir de seus simulacros: enunciador e enunciatário agora como simulacros do autor e leitor empíricos, dos indivíduos concretos que participam do circuito comunicativo. Por oposição a estes sujeitos empíricos (sujeitos de "carne e osso"), enunciador e enunciatário definem-se como "sujeitos semióticos" ("seres do discurso") que correspondem, na verdade, a funções textuais, a "papéis", a "posições" de subjetividade construídas pelo próprio texto. Podem ser definidos, enfim, como as "vozes" construídas pelo próprio texto ou como instâncias que substituem simbolicamente no texto seu autor e leitor reais. Se entendermos a própria enunciação como uma espécie de simulacro da comunicação construído no e pelo próprio texto, parece possível pensar em todos os atores envolvidos neste ato comunicativo como papéis envolvidos ora na instância da realização, ora na instância do realizado. Estes papéis corresponderiam assim, e respectivamente, aos actantes da enunciação e do enunciado, conforme o esquema a seguir:

\section{Enunciador [narrador DISCURSO narratário] Enunciatário}

Pensando as posições actanciais, no caso específico do telejornal, pode-se postular que a representação empírico-comunicativa mais imediata do sujeito enunciador desse macroenunciado, que é o telejornal no seu conjunto, parece ser todo o staff de produção do telejornal (dirigentes regionais, jornalistas, técnicos etc.) denominado, genericamente aqui de broadcaster. No nível do enunciado propriamente dito (o que se vê na tela), o narrador do telejornal corresponde à própria figura do seu apresentador (ou apresentadores). À exemplo de outros programas televisivos, o telejornal pode também representar sua audiência, de tal modo que o narratário aqui está geralmente identificado com as figurativizações do espectador no enunciado. Para isso, os telejornais apelam, mais freqüentemente, ao discurso interpelativo por meio do qual os apresentadores e repórteres dirigem-se diretamente ao espectador, seja direcionando o olhar para a câmera enquanto falam, seja utilizando vocativos ou pronomes pessoais ("você viu...", "você pode..." , "você sabe...") . É possível observar, no entanto, telejornais em que há a participação do público gravada (VTs com enoites, por exemplo) ou "ao vivo" (por meio de telefone ou internet). Embora mais rara, é possível apontar também experiências nas quais há a presença de espectadores convidados no próprio estúdio do telejornal, opinando ou participando de entrevistas com os convidados. Observamos assim, no telejornal, o esquema de papéis abaixo, no qual o termo "espectador projetado" designa essas suas diferentes figuratizações no 


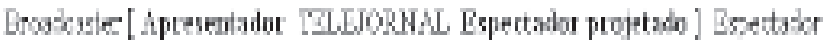

Em função da estrutura recursiva ${ }^{2}$ do telejornal, o apresentador não se constitui, no entanto, no único actante (pessoa) desse macroenunciado que é o telejornal. Todo o telejornal se organiza a partir da delegação de voz que um "eu" (quem fala), explicitamente instaurado no enunciado englobante, confere a novos actantes definidos no nível dos enunciados englobados (outros "eus"). Tratase, em outras palavras, da delegação de voz de um ator da enunciação a outro. Empiricamente, o modo mais freqüiente de se estabelecer no telejornal esta delegação de voz é a convocação pelo apresentador de um repórter ao qual cabe o relato dos fatos. Ao receber a palavra do apresentador-narrador, o repórter instaura-se então como um outro "eu", estabelecendo aqueles com quem fala como "tu". É nesse processo de delegação de voz, orientado por uma intercambialidade de posições, que o apresentador define o seu papel enunciativo: funciona como uma instância de ancoragem actancial, articulando os distintos atores da enunciação do nível enunciativo englobado com o nível englobante ${ }^{3}$. Ao fazer isso, assume o papel de um macronarrador (narrador principal) no enunciado englobante, ainda que existam vários outros narradores (secundários) no nível englobado.

\section{Papéis enunciativos e modelos de telejornal}

A partir dos papéis enunciativos dos apresentadores é possível identificar ao menos dois grandes modelos de telejornal. Há telejornais em que o apresentador funciona basicamente como um "operador de passagens" entre os vários atores da enunciação envolvidos. Nesse caso, mesmo dirigindo-se diretamente à audiência, ele não se apropria do discurso como sendo seu. Suas intervenções verbais são, geralmente, construídas em terceira pessoa e são poucas as circunstâncias nas quais se permite demonstrar uma valoração pessoal através de outros sistemas semióticos (tom da voz, expressão facial, gestos etc.). Por mais que seja tratado no universo extralingüístico como uma "estrela", nos telejornais mais convencionais, o apresentador jamais faz referência ao seu próprio papel, a si ou a quem quer que ele represente: ele nunca "fala", de modo explícito, em seu próprio nome e raramente fala em nome da própria equipe de produção do telejornal. O apresentador é um delegado imediato do sujeito enunciador que se manifesta explicitamente no enunciado (sua figurativização), mas ao qual não se pode atribuir o ponto de vista do discurso. Há aqui, portanto, uma clara distinção entre este comunicador em particular (um "eu" individual) e seu papel público, o de representante ou "porta-voz" de um broadcaster (o que o define, do ponto de vista discursivo, como um "não-eu").

Esse tipo de configuração enunciativa pode ser alinhada com o que Arlindo Machado denomina de "modelo de telejornal polifônico". Neste modelo, o apresentador é, segundo Machado, "mais exatamente um condutor em geral impessoal" (2000, p. 106), com a mesma importância dos demais integrantes da equipe, conferindo ao telejornal um caráter mais "descentralizado" em prol da construção de um maior efeito de "objetividade jornalística" . Nesse modelo de telejornal polifônico, a principal característica, em termos enunciativos, é a diluição da "voz" do apresentador em meio ao conjunto de "vozes" que o compõe. Poderíamos falar, em outros termos, na construção de um apresentador "sem voz" própria (um "eu" que não diz "eu"). Por isso mesmo, seu papel é tão somente o de um "porta-voz". Em outro modelo de telejornal que Arlindo Machado denomina de "centralizado ou opinativo", o que se observa é, ao contrário, a produção de um efeito de autonomia do apresentador frente à equipe do telejornal e à própria emissora. Investe-se, agora, deliberadamente na construção de um efeito de sentido de "dono da voz" (um apresentador dotado de "voz própria"), que assume o conteúdo enunciado como sendo seu (um "eu" que diz "eu").

\section{0 que acontece, quando este narrador-apresentador, que já se constitui em um "eu" projetado no enunciado, contraria os cânones da "objetividade jornalística" e, explicitamente, diz "eu"?}

Segundo Machado, no modelo de telejornal "centralizado ou opinativo", a voz do apresentador costuma se impor sobre as demais, emoldurando-as "com o crivo do seu comentário" (2000, p.107). Neste modelo, do qual o jornalista Boris Casoy, com o seu TJ Brasil (SBT, 19881997), foi o precursor no telejornalismo brasileiro (Squirra, 1993), o apresentador coloca-se numa posição hieraquicamente superior, de tal modo que o telejornal parece que lhe pertencer. Nesse telejornal centralizado ou opinativo, investe-se, ao contrário da configuração anterior, na deliberada oscilação dos seus apresentadores entre um "eu" (indivíduo singular, um "dono da voz") e um "não-eu" (um representante ou "porta-voz") (Landowski, 1999). Produz-se, a partir dessa oscilação, um discurso mais pessoal e, por isso mesmo, de maior empatia com o público em nome de quem os apresentadores passam, em alguns telejornais, a falar e a fazer "cobranças" ". A estratégia adotada por esse tipo de telejornal é baseada numa inequívoca personalização dos seus apresentadores, construída a partir do imbricamento, da superposição ou de uma deliberada (con)fusão entre os 
actantes do enunciado e da enunciação Trata-se aqui, em outros termos, de uma espécie de efeito de indistinção entre os atores instalados nas instâncias do enunciado e da enunciação.

\section{Reforçando a importância dos fatores exógenos na construção da credibilidade, Pierre Bourdieu propõe também que a eficácia do discurso é determinada ainda pela instituição que 0 autoriza.}

A idéia de imbricamento está aqui, de modo geral, associada à superposição de instâncias e, neste contexto específico, à (con)fusão dos papéis actanciais do enunciador com o narrador, provocando o "ofuscamento" de um pelo outro: como se um fosse "encoberto" pelo outro, como se um estivesse no lugar do outro, quase como se um fosse o outro; mas sem que um prescinda do outro. Todo esse mecanismo é determinado pelo sincretismo dos próprios papéis actanciais envolvidos no circuito enunciativo, de tal modo que se produz o efeito de que já não há um "distanciamento" entre a fonte da enunciação (enunciador) e sua figurativização (o narrador). Diluem-se, assim, os limites entre uma e outra função/ posição actancial e já não se distingue mais exatamente quem "fala" quando o apresentador do telejornal se dirige ao espectador: se um $e u$, que figurativiza no enunciado um actante coletivo da enunciação (o broadcaster) pela sua simples presença, ou um "eu" individual que agora fala também aparentemente por si (o jornalista " $x$ " ou " $y$ ").

O que acontece, então, quando este narrador-apresentador, que já se constitui em um "eu" projetado no enunciado, contraria os cânones da "objetividade jornalística" e, explicitamente, diz "eu"? Quando o apresentador, dos mais variados modos, diz "eu" (assume-se como um " $\mathrm{eu}^{\prime}$ ") é como se abandonasse a função comunicativa de "porta-voz" deste actante coletivo da enunciação, que sua presença figurativiza, para construir a si próprio como fonte do discurso (é como se um ator discursivo, o apresentador William Bonner, por exemplo, correspondesse ao indivíduo "real" William Bonner, jornalista ao qual não temos acesso a partir do que vemos no telejornal). Nessa nova configuração enunciativa, ganha mais importância a construção do apresentador como uma persona (uma espécie de "personagem" calcado na sua própria personalidade) - ou seja, um ator da enunciação que se constrói a partir de uma representação de si mesmo. Reveste-se também de maior peso o modo como, a cada edição do telejornal, vai sendo construída uma imagem do enunciador apoiada na imagem do comunicador. É diante desse tipo de configuração enunciativa que se impõe agora, ao analisarmos os telejornais, o estudo do éthos do enunciador, tal como este foi recuperado da tradição aristotélica por J. L. Fiorin (cf. 1989, 2004, 2004a). Antes, porém, é preciso recuperamos um pouco das postulações da retórica.

\section{Telejornal e retórica: 0 éthos do apresentador}

Contrariando as postulações de Platão, seu mestre, Aristóteles acreditava que a verdade não está mais no objeto, é construída no discurso. A preocupação central da retórica aristotélica é com os procedimentos de persuasão no uso público de um discurso; seu papel é fornecer ferramentas para ofazer-crer do orador. Pode ser considerada, assim, um autêntico "manual" de procedimentos para convencer o público em cada situação. Por isso, não se preocupa apenas com a construção argumentativa e incorpora também entre as suas preocupações as emoções, as paixões, os hábitos e crenças da audiência. Interessa-se não tanto pela construção da verdade, mas por tudo que possa parecer verdadeiro ao ouvinte. (Cruz Junior, 2006, pp. 19-22). Há, em razão disso, uma grande preocupação na retórica com o éthos do orador, o modo como este aparece ao público. O conceito remete, em outras palavras, à configuração de caráter por meio do qual o orador conquista a confiança da platéia com vistas à sua persuasão.

Na tradição filosófica greco-romana, o éthos foi concebido de duas maneiras distintas. Para Isócrates ou Quintiliano, era o resultado da imagem pública do orador, construída por fatores exteriores ao discurso, sobretudo os seus atributos morais (coragem, integridade etc.). Remetia, em suma, à reputação ou à fama do orador. Compreende-se assim, e em parte, a conivência das emissoras de TV com a glamourização dos seus profissionais de jornalismo, desde que essa imagem construída por outros meios que não o próprio telejornal lhes seja favorável. A freqüência com que o famoso casal de apresentadores do Jornal Nacional (TV Globo), William Bonner e Fátima Bernardes, freqüentam as revistas de celebridades dá prova disso (Hagen \& Machado, 2006). Em outros tempos, apesar na sua enorme popularidade, evitava-se a aparição de Cid Moreira - apresentador que se tornou a "marca" do JN - até mesmo nos programas da própria Globo. Hoje, ao contrário, o modo como os apresentadores constroem sua reputação junto ao público é, também, o resultado daquilo que se publica sobre eles em outras mídias ou até mesmo das suas aparições em outras programas de TV (dando entrevistas, por exemplo). Reforçando a importância dos fatores exógenos na construção da credibilidade, Pierre Bourdieu propõe também que a eficácia do discurso é determinada ainda pela instituição que o autoriza, assim como pela posição social daquele que o profere (Cruz Junior, 2006, p. 37).

Para Aristóteles e Cícero, no entanto, o éthos não dependia tanto das qualificações sociais ou dos atributos 
morais reputados ao orador. Era, sobretudo, uma construção do próprio discurso (Cruz Junior, 2006, pp.3334). No estudo do telejornal, todas essas diferentes posições parecem, no entanto, ser conciliáveis, ainda que, a depender da situação, possa se dar uma ênfase maior a uma construção ora mais empírica (pessoal) ou institucional, ora mais lingüística. Em uma discussão mais focada na instância da produção, como a proposta aqui, consideraremos a priori o éthos como um resultado da própria enunciação e adotaremos o referencial da semiótica discursiva, que não leva em consideração o "indivíduo real". Autor e o leitor reais não pertencem, portanto, ao universo textual. Apenas o autor e o leitor implícitos pertencem ao texto e, por meio deles, são apreendidos. Mesmo na autobiografia, o "eu" que se enuncia é sempre um simulacro construído do escritor, que se define no interior do texto por suas relações com os outros atores da enunciação aí instalados. O mesmo princípio vale para o estudo dos apresentadores de telejornal.

\section{0 orador que se utiliza da areté costuma mostrar-se como desbocado, franco, temerário e exerce seu convencimento sobre o auditório com base na emoção.}

Embora tenhamos, com muita facilidade, informações sobre suas vidas "reais" e pessoais pelas próprias mídias, especialmente pelas já mencionadas revistas dedicadas às celebridades, o que é importante observar é como os apresentadores constroem um éthos a partir das suas aparições diárias no telejornal. Na perspectiva adotada por J. L. Fiorin, o éthos corresponde a uma imagem do autor, não do autor real, mas do autor discursivo, um autor implícito no enunciado. Para ele, o éthos explicitase "nas marcas da enunciação deixadas no enunciado. Portanto, a análise do éthos do enunciador nada tem do psicologismo que, muitas vezes, pretende infiltrar-se nos estudos discursivos" (Fiorin, 2004, p. 120). Ainda segundo Fiorin, quando analisamos uma obra singular, podemos definir tão somente os traços do narrador. É apenas quando estudamos a obra inteira de um autor que podemos apreender, então, um éthos do enunciador $^{5}$. Fiorin lembra ainda que, para Roland Barthes, o éthos podia ser considerado como uma conotação. Consistia na propriedade que o orador possuía de, ao proferir uma informação (o dito), afirmar também algo sobre si (pelo modo de dizer).

Se admitimos que o éthos do enunciador define-se na própria enunciação, podemos concluir, então, que a influência exercida por um determinado enunciador sobre um enunciatário não depende apenas dos conteúdos que põe em circulação (enuncia): “o enunciatário não adere ao discurso apenas porque ele é apresentado como um conjunto de idéias que expressam seus possíveis interesses. Ele adere, porque se identifica com um dado sujeito da enunciação, com um caráter, com um corpo, com um tom" (Fiorin, 2004: 134). No caso do telejornal, a construção do éthos do apresentador é determinada, antes de mais nada, pela estratégia de actorialização adotada. A configuração enunciativa do apresentador, nos moldes de "porta-voz" ou "dono da voz" ("voz própria"), orienta o seu modo de dizer e parecer (aparência de ser) e influencia diretamente o fazer-crer sobre aquilo que é dito. É preciso, por isso, prestar cada vez mais atenção à "qualidade" da performance dos apresentadores ou, em outros termos, a tudo aquilo está relacionado à aspectualização do ator da enunciação (Fiorin, 1989).

\section{Éthos e aspectualização}

$\mathrm{Na}$ teoria semiótica, a aspectualização corresponde a um ponto de vista de um observador explícito ou implícito sobre o tempo, o espaço e os atores (pessoas) de uma determinada ação. No caso da aspectualização do ator, esse observador determina a "qualidade" de suas realizações, a maneira como ele desempenha suas ações. Para esse observador, um gesto de um determinado ator da enunciação (figurativizado por um palestrante, por exemplo) pode ser elegante ou desastrado, a voz pode ser estridente ou suave, a exposição pode ser segura ou hesitante. O julgamento que esse observador faz da "qualidade" da performance, no entanto, não é individual, pois seus pontos de vista são sociais, Dependem, portanto, de valorações que regem, de modo geral, as nossas relações com os outros homens (Fiorin, 1989, p.350).

De acordo ainda com o Fiorin, os comportamentos e relações sociais costumam ser pautadas pela "lógica da gradualidade" apoiada na neutralidade. Neste lógica, devem ser considerados como disfóricos (negativos) os pólos categoriais ocupados pelo excesso e pela insuficiência. O que Fiorin denomina de "justa medida" é, nesse universo relacional, o termo eufórico (positivo). A qualidade da ação positivamente valorizada na performance do ator deve ser, portanto, neutra em relação aos pólos categoriais: nem excesso, nem insuficiência, é a justa medida (neutralidade) que preside a aspectualização dos comportamentos sociais (1989, p.350). A partir desse esquema relacional, cada cultura consolida uma aspectualização positiva ou negativa dos comportamentos sociais e, conseqüentemente, da "qualidade" da performance do ator. Fiorin aponta, por exemplo, a "justa medida" em relação ao vestir como sendo sinônimo de simplicidade e sobriedade, "qualidades" que se opõem tanto ao espalhafatoso (excesso) quanto à displicência (insuficiência) (1989, pp. 352-353). Ainda como exemplos de aspectualizações do ator, definidas socialmente entre nós, ele indica várias outras valorizações disfóricas e eufóricas associadas, respectivamente, a 
performance de quem fala: exagerado (excesso) ou deficiente (insuficiência) vs. moderado (justa medida); duro (excesso) ou mole (insuficiência) vs. firme (justa medida); arrogante (excesso) ou subserviente (insuficiência) vs. humilde (justa medida); temerário (excesso) ou medroso (insuficiência) vs. prudente (justa medida); rude (excesso) ou adulador (insuficiência) vs. sincero (justa medida), entre tantas.

Se retomarmos as proposições de Fiorin sobre a aspectualização do ator, agora à luz da retórica aristotélica, parece possível concluir que as qualificações da performance de um sujeito feitas por um observador podem ser consideradas como um resultado direto da construção discursiva do seu éthos. Baseado nas descrições que a Retórica traz das características que inspiram a confiança no orador, Fiorin identifica três espécies de éthe (2004, p.121): 1) éthos baseado na phrónesis, qualidade que remete ao bom senso, a prudência, a ponderação, indicando se o orador exprime opiniões competentes e razoáveis; 2) éthos baseado na areté, que remete à virtude, entendida, neste contexto, como coragem, justiça e sinceridade, o que se traduz na manifestação do orador como alguém simples, sincero e franco ao expor seus pontos de vista; 3) éthos baseado na eúnoia, que remete à benevolência e à solidariedade, associadas às demonstrações de simpatia do orador pelo auditório. De acordo com Fiorin, o orador que se utiliza da phrónesis se apresenta como sensato, ponderado e exerce sua persuasão muito mais com os recursos discursivos (argumentivos). $\mathrm{O}$ orador que se utiliza da areté costumar mostrar-se como desbocado, franco, temerário e exerce seu convencimento sobre o auditório com base na emoção. Já aquele que usa a eúnoia apresenta-se como alguém solidário e benevolente com seu enunciatário, conquistando-o por meio da simpatia.

É evidente que por tratar da performance de um orador diante do auditório, todas essas qualidades descritas na Retórica devem ser repensadas a partir das especificidades do aparato enunciativo analisado. Para pensarmos, por exemplo, a construção da imagem do enunciador nos jornais, será preciso considerar outras "marcas" que dependem das especificidades técnicoexpressivas do meio. Para se estabelecer os éthe do que se chama, comumente, imprensa séria e imprensa sensacionalista, por exemplo, é preciso observar, entre outras coisas, o modo como num corpus formado a partir de um conjunto representativo de edições, os jornais trabalham recorrentemente com determinados arranjos no conteúdo (temas predominantes, tipo de abordagem, manchetes etc.) e na expressão (fotos, fontes, cores etc. ${ }^{6}$. No caso dos apresentadores de telejornal, é possível postular a construção de dois tipos de éthos que podem ser homologados, em pólos opostos, às duas configurações enunciativas descritas anteriormente ("porta-voz" e "dono da voz"): o apresentador-impessoal (distante) e o apresentador-cúmplice (próximo), respectivamente.

Definindo-os a partir da sua aspectualização, pode- mos associar às descrições dos éthe dos apresentadores, a comportamentos e qualidades que caracterizam sua performance. O éthos do apresentador-impessoal pode ser reconhecido pela formalidade e por uma postura corporal mais tensa, pela contenção gestual e pela mono tonalidade. Esse tipo de apresentador evidencia uma obediência mais estrita ao texto escrito (script), evitando improvisações ou mesmo exprimir emoções. Toda a sua performance é orientada por um apelo mais deliberado à racionalidade e inteligibilidade do telespectador. Tratase aqui de um comportamento baseado na phrónesis, nos termos descritos por Aristóteles, e de uma postura orientada rumo à insuficiência, nos termos de Fiorin. A performance do apresentador-cúmplice, ao contrário, apela à afetividade e passionalidade do telespectador. Para a construção desse tipo oposto de éthos, costuma adotar um comportamento mais informal e uma a postura corporal mais relaxada. Seu gestual é mais espontâneo e menos contido, suas expressões faciais são usadas deliberadamente como forma de comentário. Sua entonação varia com freqüência, sendo utilizada também para exprimir seus estados de alma, seja de comoção ou indignação (é o tipo de apresentador que "esbraveja" ou fala muito alto, por exemplo). A performance desse tipo de apresentador é comparável, nos termos da retórica aristotélica, a do orador que se utiliza da areté. Seu comportamento tende ao pólo do excesso, nos termos de Fiorin.

\section{Ainda preliminarmente, parece também possível apontar que a grande aceitação do modelo de telejornal centralizado e opinativo, no qual se dá ainda mais ênfase à construção do éthos do enunciador.}

É possível ainda identificar e descrever posições intermediárias entre esses termos opostos que nos levariam ainda a outros dois tipos de éthos que, por meio de manifestações distintas, tenderiam igualmente à "justa medida" (Fiorin, 1989). Bastaria, por meio de uma operação lógica, negarmos os termos opostos com os quais operamos até aqui para chegarmos a dois outros éthe. Se pensarmos, por exemplo, em um apresentador que pode ser qualificado como não-cúmplice, poderíamos propor a sua descrição como um apresentador-crítico. Esse tipo de apresentador não se comporta com a formalidade e contensão próprias ao apresentador-impessoal, mas, como este, investe mais na racionalidade que na emoção. Expõe, no entanto, suas posições e sentimentos por comen- 
tários, expressões ou entonações discretamente irônicos, céticos, bem-humorados (ou mal-humorados), por exemplo. Na sua postura, evidencia-se um convencimento de que, apesar da sutileza das suas intervenções, elas serão bem compreendidas

Pelo mesmo caminho, propondo a negação do outro pólo categorial (o do apresentador-impessoal), chegaríamos ao éthos baseado no não-impessoal, que propomos associar, aqui, à descrição de um apresentador-comprometido, cujo comportamento é caracterizado pela busca de empatia com o público, mas sem que, para isso, tenha que assumir posições político-ideológicas explícitas ou encenar bravatas. Seu esforço para construir uma maior proximidade do telespectador manifesta-se, freqüentemente, por meio de comentários simpáticos e de natureza pessoal, que tentam construir a si mesmo como "homem comum", alguém com os mesmos gostos, preocupações, interesses e problemas cotidianos do telespectador.

Pensados em termos da retórica aristotélica, esses dois ethé - o comprometido e o crítico - baseiam-se em distintos modos de atualização da eúnoia, a partir de uma valorização maior do próprio telespectador, e não tanto do protagonismo do apresentador, como ocorre no pólo categorial de base - do impessoal e do cúmplice. Neste pólo, a valorização do apresentador evidencia-se tanto pelo modo como ele assume seu discurso como "a verdade" (caso do apresentador-impessoal), quanto pela maneira como toma para si o direito de "falar pelos outros" (caso do apresentador-cúmplice). A valorização do telespectador, ao contrário, aparece em todas as situações em que o apresentador esforça-se por tratá-lo como "igual", seja por meio da busca de empatia nos comportamentos/hábitos/gostos, seja por meio das sinalizações discretas, tecidas na entrelinhas muita vezes, quanto aos repertórios compartilhados ou a visões de mundo comuns (postura do tipo "você sabe do que estou falando...").

Embora não possamos, na atual etapa do estudo e nos limites deste artigo, caracterizar o éthos dos nossos principais apresentadores de telejornal, parece possível, a partir dessa abordagem teórica, assumir já como hipótese a possibilidade de alinhá-los em uma dessas quatro posições. A comprovação dessa hipótese depende, no entanto, do acompanhamento em curso da performance de cada apresentador em um conjunto grande de aparições diárias, pois só assim parece possível fundamentar a configuração de um tipo particular de éthos, assim como sua relação com o modelo enunciativo e com a proposta editorial do telejornal. É importante ressalvar, no entanto, que o alinhamento das performances dos apresentadores nesses quatro pólos (impessoal/cúmplice, crítico/comprometido) servirá apenas para orientar a descrição de um tipo de éthos predominante. É este, ao final, que norteará a interação entre o telespectador e o apresentador, assim como os processos de identificação do próprio telejornal. Não se exclui aqui, no entanto, o deslocamento dos apresentadores, inclusive numa mesma edição do telejornal, entre um pólo e outro, assumindo posições intermediárias ou graduais em função dos conteúdos proferidos ${ }^{7}$.

Ainda preliminarmente, parece também possível apontar que a grande aceitação do modelo de telejornal centralizado e opinativo, no qual se dá ainda mais ênfase à construção do éthos do enunciador, parece ser um indicativo de que a credibilidade do apresentador já não se mede mais pela aparente "objetividade" ou pela lógica da neutralidade ${ }^{8}$. A credibilidade depende hoje muito mais da sua capacidade de criar o espaço necessário à valoração e ao questionamento das notícias que chegam ao espectador em profusão e frente às quais ele, geralmente, tem dificuldades de avaliação (Verón, 1995, p. 88). Esse novo papel assumido pelo apresentador (âncora) produz agora um contrato de veridicção (um crerverdadeiro) que não se baseia mais em estratégias para mascarar o fato evidente de que toda produção de linguagem emana de alguém e se dirige a alguém para falar de alguma coisa. Não se pretende mais, portanto, confundir uma pretensa "neutralidade" do apresentador com uma objetivação do texto. O atributo de "verdade" que se confere ao seu discurso é, agora, proporcional à credibilidade que conquista junto ao telespectador, a partir, especialmente, do éthos construído pelo próprio telejornal $\square$ famecos

\section{NOTAS}

* Versão revista do texto apresentado ao Grupo de Trabalho "Estudos de Jornalismo", no XVII Encontro da Compós, na UNIP, em São Paulo, em junho de 2008.

1. Para discutir sobre a enunciação no telejornal, recuperamos, e ampliamos, postuaçõesteóricas desenvolvidas, inicialmente,em Fechine 2001, 2001a.

2. Uma estrutura é recursiva quando a configuração mais geral pode também ser observada nas suas partes (repetição do todo nas partes).

3. No Dicionário de Semiótica, o termo ancoragem designa "o ato de pôr em relação duas grandezas semióticas pretencentes quer a duas semióticas diferentes (a imagem publicitária e a legenda; o quadro e seu nome), quer a duas instâncias discursivas distintas (texto e título)" (Greimas \& Courtés 1983, p.21). A ancoragem permite que, ao serem postas em relação, uma grandeza funcione como referência da outra. É precisamente nessa acepção que utilizamos o termo aqui: o apresentador funciona como uma "âncora" semiótica na definição do papel de cada um dos outros participantes do telejornal (repórteres, comentaristas, convidados etc.). Essa ancoragem é necessária porque, considerada isoladamente, cada reportagem constrói um dispositivo enunciativo semelhante 
ao do telejornal como um todo (constrói um outro narrador-repórter que, por sua vez, dá "voz" a outros atores da enunciação), criando assim a necessidade de retorno à instância englobante a cada delegação efetivada no nível englobado.

4. Conscientes do respaldo que os âncoras dos telejornais de modelo opinativo construíram junto à sua audiência, justamente através desse seu personalismo, homens públicos (políticos, empresários, políticos, representantes de órgãos governamentais etc.) acabam, muito freqüentemente, dando explicações e assumindo compromissos com os própriosos apresentadores do telejornal; agemcomo se estes fossem as autênticas instâncias às quais devem prestar contas

5. No estudo dos telejornais, essa postulação implica em uma orientação metodológica: não pode se basear a descrição do éthos de um apresentador na análise de um único programa, mas em um conjunto amplo de exibições (edições) e situações.

6. Fiorin indica como referência no estudo do éthos do enunciador nas mídias o livro de Norma Discini de Campos intitulado O estilo nos textos. São Paulo, Contexto, 2000 (cf. 2004a).

7. Tome-se como exemplo disso a edição do JN, de 06/ 08/03,em que, ao noticiar a morte do então presidente das Organizações Globo, Roberto Marinho, William Bonner embargou a voz e quase chorou, evidenciado toda a sua comoção ao anunciar a morte do patrão. Numa avaliação preliminar do éthosconstruído por Bonner, no JN, seu comportamento estaria mais alinhado ao do apresentador-impessoal, que contém suas emoções e juízos de valor. No entanto, esse alinhamento não é estático, já que o apresentador pode assumir também outras posturas, sem que estas sejam predominantes, ou ao menos as mais recorrentes, na observação da sua performance no JN.

8. O termo "neutralidade" é empregado aqui no sentido proposto por Fiorin (1989), mas alude também à sua acepção nos estudos de jornalismo nos quais está, geralmente, associado à noção de imparcialidade.

\section{REFERÊNCIAS}

CRUZ JUNIOR, Dilson Ferreira. O Éthos do enunciador nos romances de Machado de Assis: uma abordagem semiótica. USP:FFLCH, Programa de Pós-graduação em Semiótica e Lingüística Geral, Tese de Doutorado, São Paulo, 2006.
FECHINE, Yvana. Televisão e presença: uma abordagem semiótica da transmissão direta em gêneros informativos. Tese de doutorado, Programa de Estudos Pós-graduados em Comunicação e Semiótica - PUCSP, 2001.

. Estratégias de personalização dos apresentadores do SPTV: uma abordagem semiótica do problema, in Antonio Fausto Neto et. al. (orgs.), Práticas midiáticas e espaço público, EDIPUCRS/Famecos, Porto Alegre, 2001a.

FIORIN, José Luiz. O Éthos do enunciador, in A. Cortina A. R. Marchezan (org.), Razões e sensibilidades: a semiótica em foco. Araraquara (SP): Laboratório Editorial FLC/UNESP/Cultura Acadêmica Editora, 2004.

. Semiótica e Comunicação. Galáxia - Revista Transdisciplinar de Comunicação, semiótica, cultura, NÚ8. São Paulo: EDUC.

. A lógica da neutralidade: um caso de aspectualização do ator. XVIII Anais de Seminários do GEL (Grupo de Estudos Linguísticos de São Paulo). São Paulo: Dedalus/Acervo USP-FFLCH-LE, 1989.

GREIMAS, Algirdas Julien \& COURTÉS, Joseph. Dicionário de semiótica (trad. port. Alceu Amoroso Lima et al.), Tomo I. São Paulo: Cultrix, 1983.

HAGEN, Sean e MACHADO, Márcia B. Jornalismo e o mito da perfeição andrógina. UNIrevista, Vol. 1, NÚ3, Unisinos, Porto Alegre (RS), 2006.

LANDOWSKI, Eric. Diana, in vivo, in O. Quezada Macchiavello (ed.), Froteras de la semiótica. Homenaje a Desiderio Blanco. Universidad de Lima/ Fondo de Cultura Económica: Peru, Lima, 1999.

MACHADO, Arlindo. A televisão levada a sério. São Paulo: SENAC, 2000.

SQUIRRA, Sebastião. Boris Casoy: o âncora no telejornalismo brasileiro. Petrópolis (RJ): Vozes, 1993.

VÉRON, Eliseo. Construir el acontecimento. Barcelona: Gedisa Editorial, 1995. 